\title{
Mn2+: A potent antioxidant and stimulator of sperm capacitation and acrosome reaction in crossbred cattle bulls
}

\begin{abstract}
Manganese is a well known antioxidant and is a potent inhibitor of in vitro oxidative stress. The aim of this work was to study the influence of $\mathrm{Mn}^{2+}(60 \mu \mathrm{M})$ on capacitation and acrosome reaction of crossbred cattle bull spermatozoa. Fresh semen was centrifuged and pellet so obtained was suspended in TALP medium (pH 7.4). The sperm suspension was divided into four equal fractions(four tubes). In the control tube, only TALP was added; whereas the remaining three tubes were supplemented with ferrous ascorbate (FeAA - $150 \mu \mathrm{M} \mathrm{FeSO} 4: 750 \mu \mathrm{M}$ ascorbic acid) , $60 \mu \mathrm{M} \mathrm{Mn}^{2+}$ and FeAA $+\mathrm{Mn}^{2+}$, respectively All fractions were incubated incubated (37 $\left.{ }^{\circ} \mathrm{C}\right)$ for $6 \mathrm{hr}$ in $\mathrm{CO}_{2}$ incubator. These fractions were assessed for morphology, \% hyperactivity, lipid peroxidation (LPO) and \% acrosome reaction. Morphology of the capacitated spermatozoa remained unaltered with FeAA/Mn ${ }^{2+} / \mathrm{FeAA}^{+} \mathrm{Mn}^{2+}$ treatments. FeAA treatment non-significantly ( $\mathrm{p} \geq 0.05$ ) decreased \% sperm hyperactivity \% acrosome reaction, but, increased the LPO level. Supplementation of $\mathrm{Mn}^{2+}$ increased \% hyperactivity and \% acrosome reaction significantly $(\mathrm{p} \leq 0.05)$ in FeAA untreated fractions, but, non-significantly $(\mathrm{p} \geq 0.05)$ in FeAA treated fractions. Malondialdehyde (MDA - end product of LPO) decreased significantly $(\mathrm{p} \leq 0.05)$ with the $\mathrm{Mn}^{2+}$ supplementation both in FeAA treated and untreated fractions. It is concluded that $\mathrm{Mn}^{2+}$ protects the bull sperm against LPO/oxidative stress and facilitates the occurrence of capacitation and acrosome reaction.
\end{abstract}

Key words: FeAA; $\mathrm{Mn}^{2+}$; sperm capacitation; acrosome reaction; Lipidperoxidation

\section{Zusammenfassung}

Titel der Arbeit: $\mathbf{M n}^{2+}$ als Antioxidanz und Stimulator für die Kapazitierung und Akrosomenreaktion von Sperma bei Kreuzungsbullen.

Magnesium ist bekannt als Antioxidanz und Hemmstoff für in vitro oxidativen Stress. Ziel dieser Studie war die Untersuchung des Einflusses von $\mathrm{Mn}^{2+}(60 \mu \mathrm{M})$ auf die Kapazitation und Akrosomenreaktion bei Sperma von Kreuzungsbullen. Das Frischsperma wurde zentrifugiert, pelletiert und anschließend TALP Medium $(\mathrm{pH} 7,4)$ ausgesetzt. Danach erfolgte eine Aufteilung in vier gleiche Fraktionen. Die Proben der ersten Fraktion enthielten nur TALP Medium, während den verbleibenden drei Proben Eisenascorbit (FeAA - $150 \mu \mathrm{M} \mathrm{FeSO}_{4}: 750 \mu \mathrm{M}$ Ascorbinsäure), $60 \mu \mathrm{M} \mathrm{Mn}^{2+}$ beziehungsweise FeAA+ $\mathrm{Mn}^{2+}$ zugesetzt wurde. Alle Fraktionen wurden sechs Stunden bei $37^{\circ}$ in $\mathrm{CO}_{2}$ inkubiert und anschließend hinsichtlich Morphologie, prozentualer Hyperaktivität, Lipidperoxidation (LPO) sowie prozentualer Akrosomenreaktion bewertet. Morphologisch unverändert blieb die Spermienkapazitation der FeAA/ $\mathrm{Mn}^{2+} / \mathrm{FeAA}+\mathrm{Mn}^{2+}$ behandelten Fraktion. Die FeAA Behandlung ergab keine signifikante $(\mathrm{p}=0,05)$ Verminderung der Sperma Hyperaktivität und der prozentualen Akrosomenreaktion, aber eine Erhöhung des LPO Spiegels. Ein $\mathrm{Mn}^{2+}$ Zusatz ergab eine signifikante Erhöhung der prozentualen Hyperaktivität und Akrosomenreaktion gegenüber der FeAA unbehandelten Fraktion, aber keine signifikante Erhöhung in der FeAA Fraktion. Malondialdehyd (MDA - Endprodukt von LPO) verminderte signifikant die $\mathrm{Mn}^{2+}$ ergänzten FeAA und nicht FeAA behandelten Fraktionen. Es wird geschlussfolgert, dass $\mathrm{Mn}^{2+}$ Bullensperma gegen LPO und oxidativen Stress schützen kann und die Vorgänge der Spermakapazitation und Akrosomenreaktion erleichtert werden.

Schlüsselwörter: FeAA, $\mathrm{Mn}^{2+}$, Sperma, Kapazitation, Akrosomenreaktion, Lipidperoxidation 


\section{Introduction}

For successful fertilization, mammalian spermatozoa must undergo a preparation period known as capacitation (O’FLAHERTY et al., 1999). In physiological terms, capacitation can be considered as the sum of biochemical and biophysical modifications that take place in sperm cell during its transport through the female genital tract (PARRISH et al., 1999). These modifications regulate temporary changes in the pattern of sperm motility referred to as hyperactivation. This process culminates in an exocytotic event called acrosome reaction, an essential step to fertilize oocytes (O’FLAHERTY et al., 1997).

Mammalian spermatozoa represents a growing list of cell types that exhibit a capacity to generate highly reactive oxygen species (ROS). Controlled generation of ROS has a physiological role in spermatozoal functions such as hyperactivation, capacitation and acrosome reaction (de LAMIRANDE et al., 1993;GRIVEAU et al., 1997;O'FLAHERTY et al.,2005). Uncontrolled and excessive ROS production or exposure of spermatozoa to fatty acidperoxides or the combination of ferrous ions $\left(\mathrm{Fe}^{2+}\right)$ and ascorbic acid (AA) at high concentrations induces lipid peroxidation (LPO) / oxidative stress, resulting in decreased sperm motility, viability and increased mid-piece defects that impair capacitation and acrosome reaction ( de LAMIRANDE et al., 1993 \& 1995; BANSAL and BILASPURI, 2007). Therefore, an antioxidant that reduces oxidative stress and improves spermatozoal functions could be useful in the management of male infertility ( VERMA and KANWAR, 1999).Antioxidants are the agents, which break the oxidative chain reaction, thereby, reducing the oxidative stress (MILLER and SLEBODZINSKA, 1993; KUMAR and MAHMOOD,2001). A variety of biological antioxidants that attack ROS and LPO are presently under investigation (SIKKA, 1996).

The antioxidative action of Mn (II) on different peroxidizing systems has been studied. It inhibits LPO produced by free radical producing system but not the one induced by singlet oxygen (CAVALLINI et al., 1984). Manganese in very - very small amount affects human health and participates in many enzymatic activities( SINGH, 2008). It is an essential component of several enzymes and some of them (superoxide dismutase, pseudo-catalase and the photosynthetic oxygen evolving centre) are involved in redox processes. Manganese has also been assigned as a chain breaking antioxidant, as it is able to quench the peroxyl radicals (COASSIN et al., 1992).

The present study was undertaken to examine the effect of $60 \mu \mathrm{M} \mathrm{Mn} 2+$ on morphology, $\%$ hyperactivity, \% acrosome reaction and changes in lipid peroxidation (LPO) level during capacitation and acrosome reaction of crossbred cattle bull spermatozoa.

Materials and methods

Semen samples $(\mathrm{n}=5)$ with more than $80 \%$ motility and $1200 \times 10^{6}-1400 \times 10^{6} / \mathrm{ml}$ sperm count were obtained from the healthy local crossbred cattle bulls (HHS, HolsteinFriesian $\mathrm{x}$ Sahiwal; FC, Friesian crosses; $1 \mathrm{~F}$ and 4F first and fourth generation of interbreeding) maintained at the Dairy Farm, Guru Angad Dev Veterinary and Animal Sciences University, Ludhiana. Each parameter was analysed by using three replicates of a single ejaculate of each bull;total five bulls were studied. A known volume of semen 
sample was taken in a centrifuge tube (prewarmed at $37^{\circ} \mathrm{C}$ ) which was centrifuged (x 800 g, 5 minutes); seminal plasma was removed, sperm pellet was washed 2-3 times with TALP medium $\left(\mathrm{NaCl}-92.9 \mathrm{mM} ; \mathrm{KCl}-4 \mathrm{mM} ; \mathrm{NAHCO}_{3}-25.9 \mathrm{mM} ; \mathrm{CaCl}_{2} .2 \mathrm{H}_{2} \mathrm{O}-\right.$ $10 \mathrm{mM} ; \mathrm{MgCl}_{2} \cdot 6 \mathrm{H}_{2} \mathrm{O}-0.5 \mathrm{mM}$; sodium lactate $-7.6 \mathrm{mM}$; sodium pyruvate $-1.3 \mathrm{mM}$; HEPES - 20mM; glucose - 0.25\%; heparin - $200 \mu \mathrm{g} / \mathrm{ml}$ and BSA - 0.6\%). Pellet was dissolved in TALP medium ( $\mathrm{pH} 7.4$ ) to prepare sperm suspension which was divided into four equal fractions(four tubes). In the control tube, only TALP was added; whereas the remaining three tubes were supplemented with ferrous ascorbate $\left(\mathrm{FeAA}-150 \mu \mathrm{M} \mathrm{FeSO}_{4}\right.$ : $750 \mu \mathrm{M}$ ascorbic acid) ( best dose of oxidative stress inducer, suggested by BANSAL and BILASPURI,2008), $60 \mu \mathrm{M} \mathrm{Mn}{ }^{2+}$ ( best dose of antioxidant, suggested by BANSAL,2006) and FeAA $+\mathrm{Mn}^{2+}$, respectively All fractions were incubated $\left(37^{\circ} \mathrm{C}\right)$ for $6 \mathrm{hr}$ in $\mathrm{CO}_{2}$ incubator. Thereafter, control and experimental fractions were evaluated for the following parameters at varying incubating periods.

Percentage motility or hyperactivity:

It was observed at $0^{-}, 2^{-}, 4^{-}, 6^{-} \mathrm{hr}$ of incubation by direct light microscopy.

Morphology and percentage acrosome reaction:

Smears of each fraction were prepared at $2 \mathrm{hr}$ interval, stained with Giemsa and examined under oil emulsion using binocular microscope and percentage acrosome reaction and morphology of spermatozoa of all fractions were compared.

\section{Lipid peroxidation (LPO):}

Malondialdehyde (MDA - end product of LPO) was determined by the thiobarbituric acid (TBA) assay (BUEGE and STEVEN, 1978).

'Analysis of Factorial Experiment in CRD'(computer software programme) or 'one way variance analysis' was used to evaluate the significance levels between the parameters studied. Bull to bull variations were negligible , therefore, the effect of factor bull was not considered. The critical difference (CD) of three factors- A (incubation period), B (control and treatments) and $\mathrm{AB}$ (interaction between incubation periods and treatments) obtained were used to find the level of significance. A ' $P$ ' value of 0.05 was selected as a criterion for statistically significant differences.

\section{Results}

\section{Morphology:}

Morphology of bull spermatozoa remains unaffected with FeAA/ $\mathrm{Mn}^{2+} / \mathrm{FeAA}+\mathrm{Mn}^{2+}$ treatments, however, the spermatozoa undergo normal process of capacitation and acrosome reaction. The stages during these processes observed in bull spermatozoa are clearly seen in Figs. 1 to 4. 


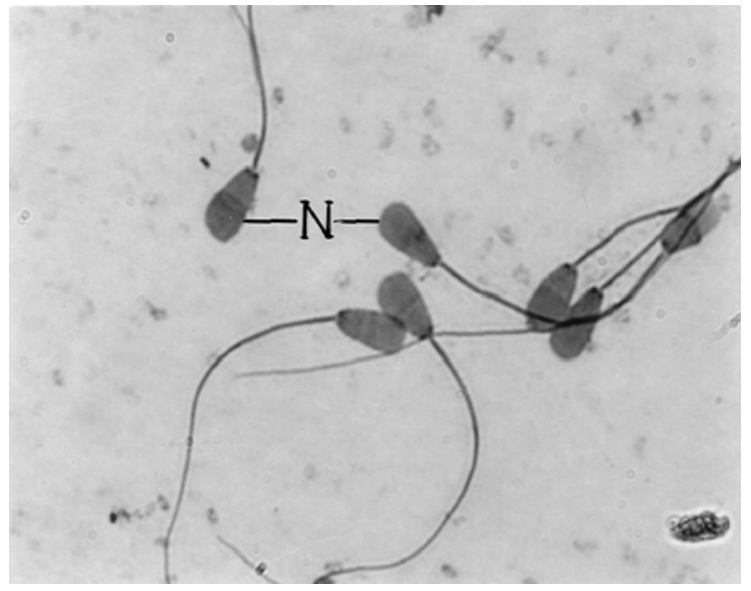

Fig. 1: Cattle bull spermatozoa incubated for $2 \mathrm{hr}$ in $\mathrm{Mn}^{2+}(60 \mu \mathrm{M})$ at $37^{\circ} \mathrm{C}$. The capacitation has not started yet and spermatozoa show normal (N)morphology.

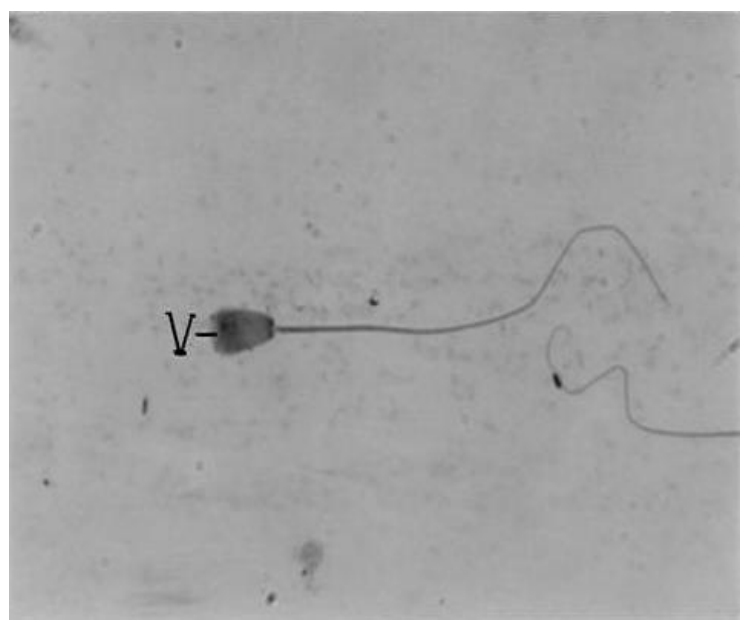

Fig. 3: Cattle bull spermatozoa incubated for $4 \mathrm{hr}$ in $\mathrm{Mn}^{2+}(60 \mu \mathrm{M})$ at $37^{\circ} \mathrm{C}$. The capacitation has advanced further as shown by vesiculation (V) in the head region.

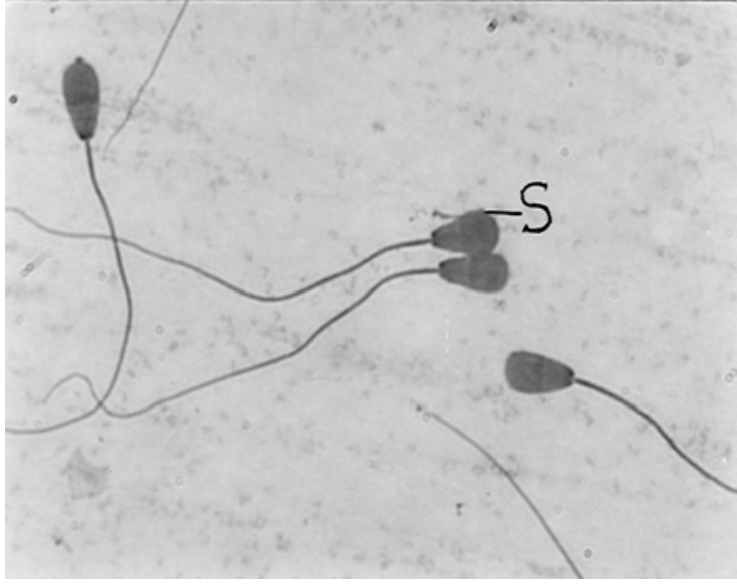

Fig. 2: Cattle bull spermatozoa incubated for $4 \mathrm{hr}$ in $\mathrm{Mn}^{2+}(60 \mu \mathrm{M})$ at $37^{\circ} \mathrm{C}$. The capacitation has has started as shown by swelling (S)in the head region.

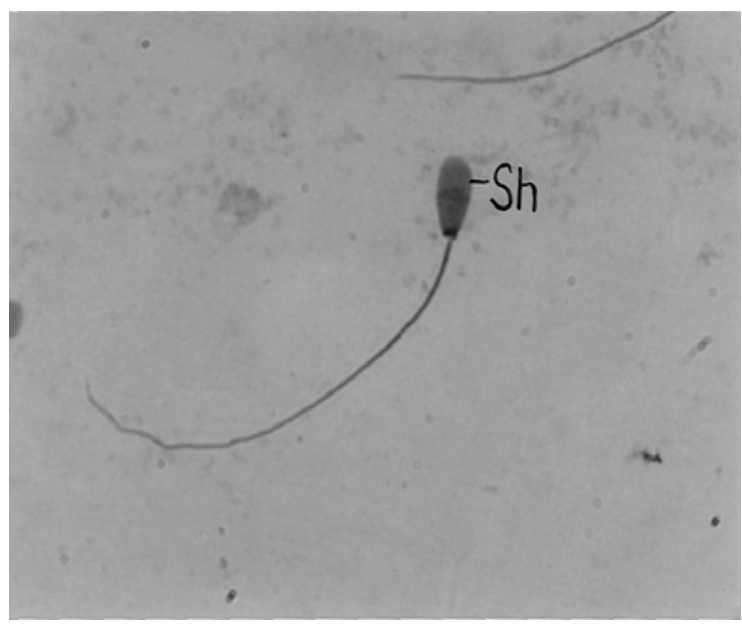

Fig. 4: Cattle bull spermatozoa incubated for $6 \mathrm{hr}$ in $\mathrm{Mn}^{2+}(60 \mu \mathrm{M})$ at $37^{\circ} \mathrm{C}$. The shedding ( Sh) of the acrosomal cap show the occurrence of acrosome reaction.

\section{Hyperactivity (\%):}

Corresponding to the incubation period, \% hyperactivity of spermatozoa decreased nonsignificantly ( $\mathrm{P} \geq 0.05)$ upto $2 \mathrm{hr}$, but, significantly $(\mathrm{P} \leq 0.05)$ upto $6 \mathrm{hr}$ as compared to $0 \mathrm{hr}$ (Table 1). Treatment of spermatozoa with FeAA decreased the hyperactivity nonsignificantly $(\mathrm{P} \geq 0.05)$. However, $\mathrm{Mn}^{2+}$ supplementation increased it significantly $(\mathrm{P} \leq 0.05)$ in FeAA untreated but non-significantly $(\mathrm{P} \geq 0.05)$ in FeAA treated samples (Table 1). Statistical analysis has shown non-significant $(\mathrm{P} \geq 0.05)$ interaction between treatments and incubation periods. Thus, increase or decrease in \% hyperactivity with various treatments is not affected by incubation periods or vice-versa. 
Table 1

Effects of FeAA/Mn ${ }^{2+} / \mathrm{FeAA}+\mathrm{Mn}^{2+}$ on \% hyperactivity of bull spermatozoa duringcapacitation and acrosome reaction. (Einfluss von FeAA/ $\mathrm{Mn}^{2+} / \mathrm{FeAA}+\mathrm{Mn}^{2+}$ auf prozentuale Hyperaktivität von Bullensperma während Kapazitation und Akrosomenreaktion)

\% hyperactivity

\begin{tabular}{|c|c|c|c|c|c|}
\hline \multirow{2}{*}{$\begin{array}{l}\text { Incubationperiod } \\
\text { (hr) }\end{array}$} & \multicolumn{2}{|c|}{ FeAA untreated } & \multicolumn{2}{|c|}{ FeAA treated } & \multirow{2}{*}{$\begin{array}{l}\text { Combination } \\
\text { factor mean }\end{array}$} \\
\hline & Control & $\mathrm{Mn}^{2+}$ & FeAA & $\mathrm{FeAA}+\mathrm{Mn}^{2+}$ & \\
\hline 0 & $\begin{array}{l}73.888 \\
\pm 1.367\end{array}$ & $\begin{array}{l}74.166 \\
\pm 1.416\end{array}$ & $\begin{array}{l}72.5 \\
\pm 0.962\end{array}$ & $\begin{array}{l}73.055 \\
\pm 1.510\end{array}$ & $73.402^{\mathrm{a}}$ \\
\hline 1 & $\begin{array}{l}72.222 \\
\pm 1.0718\end{array}$ & $\begin{array}{l}76.388 \\
\pm 1.118\end{array}$ & $\begin{array}{l}71.388 \\
\pm 1.047\end{array}$ & $\begin{array}{l}74.166 \\
\pm 1.521\end{array}$ & $73.541^{\mathrm{a}}$ \\
\hline 2 & $\begin{array}{l}72.166 \\
\pm 0.881\end{array}$ & $\begin{array}{l}73.055 \\
\pm 1.228\end{array}$ & $\begin{array}{l}71.944 \\
\pm 1.609\end{array}$ & $\begin{array}{l}72.5 \\
\pm 1.360\end{array}$ & $72.416^{\mathrm{a}}$ \\
\hline 3 & $\begin{array}{l}69.444 \\
\pm 1.289\end{array}$ & $\begin{array}{l}71.666 \\
\pm 1.521\end{array}$ & $\begin{array}{l}68.611 \\
\pm 1.422\end{array}$ & $\begin{array}{l}70.555 \\
\pm 1.095\end{array}$ & $70.069^{\mathrm{b}}$ \\
\hline 4 & $\begin{array}{l}67.5 \\
\pm 2.187\end{array}$ & $\begin{array}{l}69.444 \\
\pm 1.458\end{array}$ & $\begin{array}{l}66.111 \\
\pm 1.928\end{array}$ & $\begin{array}{l}68.333 \\
\pm 1.360\end{array}$ & $67.847^{\mathrm{c}}$ \\
\hline 5 & $\begin{array}{l}62.222 \\
\pm 2.338\end{array}$ & $\begin{array}{l}65.833 \\
\pm 2.515\end{array}$ & $\begin{array}{l}61.944 \\
\pm 2.214\end{array}$ & $\begin{array}{l}65.000 \\
\pm 1.883\end{array}$ & $63.75^{\mathrm{d}}$ \\
\hline 6 & $\begin{array}{l}59.166 \\
\pm 2.545\end{array}$ & $\begin{array}{l}63.055 \\
\pm 2.349\end{array}$ & $\begin{array}{l}57.777 \\
\pm 2.705\end{array}$ & $\begin{array}{l}61.666 \\
\pm 2.319\end{array}$ & $60.416^{\mathrm{e}}$ \\
\hline $\begin{array}{l}\text { Combination } \\
\text { factor mean }\end{array}$ & $68.087^{\mathrm{a}}$ & $70.515^{\mathrm{b}}$ & $67.182^{\mathrm{a}}$ & $69.325^{\mathrm{a}}$ & \\
\hline
\end{tabular}

Any two means in a row or column having different superscripts (a, b, c, d, e) are significantly different at $5 \%$ level of significance.

\section{Lipid peroxidation and \% acrosome reaction:}

Corresponding to the incubation period, LPO of all fractions increased significantly $(\mathrm{P} \leq 0.05)$ after $4 \mathrm{hr}$ and $6 \mathrm{hr}$ as compared to $0 \mathrm{hr}$ of incubation (Table 2). FeAA treatment to the bull sperm increased the LPO non-significantly $(\mathrm{P} \geq 0.05)$. However, supplementation of $\mathrm{Mn}^{2+}$ decreased the MDA production significantly $(\mathrm{P} \leq 0.05)$ in both FeAA treated and untreated spermatozoal samples (Table 2). Statistical analysis shows non-significant interaction $(\mathrm{P} \geq 0.05)$ between treatments and incubation periods, thus, increase or decrease in LPO with treatments is not affected by incubation periods or viceversa.

The \% acrosome reaction of bull spermatozoa increased significantly $(\mathrm{P} \leq 0.05)$ from $4 \mathrm{hr}$ to $6 \mathrm{hr}$ (Table 3). FeAA treatment decreased the \% acrosome reaction non-significantly $(\mathrm{P} \geq 0.05)$ as compared to the control. Subsequently, supplementation of $60 \mu \mathrm{M} \mathrm{Mn}{ }^{2+}$ increased \% acrosome reaction significantly $(\mathrm{P} \leq 0.05)$ in FeAA untreated, but, nonsignificantly $(\mathrm{P} \geq 0.05)$ in FeAA treated fractions (Table 3). Statistical analysis shows nonsignificant $(P \geq 0.05)$ interaction between the treatments and incubation periods. Thus, increase or decrease in acrosome reaction with various treatments is not affected by incubation periods or vice-versa. 
Table 2

Effects of $\mathrm{FeAA} / \mathrm{Mn}^{2+} / \mathrm{FeAA}+\mathrm{Mn}^{2+}$ on lipid peroxidation of bull spermatozoa during capacitation and acrosome reaction. (Einfluss von FeAA/ $\mathrm{Mn}^{2+} / \mathrm{FeAA}+\mathrm{Mn}^{2+}$ auf Lipidperoxidation von Bullensperma während Kapazitation und Akrosomenreaktion)

n moles MDA/ $\mu g$ protein

\begin{tabular}{|c|c|c|c|c|c|}
\hline \multirow{2}{*}{$\begin{array}{l}\text { Incubationperiod } \\
\text { (hr) }\end{array}$} & \multicolumn{2}{|c|}{ FeAA untreated fractions } & \multicolumn{2}{|c|}{ FeAA treated Fractions } & \multirow{2}{*}{$\begin{array}{l}\text { Combination } \\
\text { factor mean }\end{array}$} \\
\hline & Control & $\mathrm{Mn}^{2+}$ & FeAA & $\mathrm{FeAA}+\mathrm{Mn}^{2+}$ & \\
\hline 0 & $\begin{array}{l}2.146 \\
\pm 0.473\end{array}$ & $\begin{array}{l}2.016 \\
\pm 0.551\end{array}$ & $\begin{array}{l}3.385 \\
\pm 0.541\end{array}$ & $\begin{array}{l}2.491 \\
\pm 0.694\end{array}$ & $2.510^{\mathrm{a}}$ \\
\hline 4 & $\begin{array}{l}4.663 \\
\pm 1.171\end{array}$ & $\begin{array}{l}2.833 \\
\pm 0.399\end{array}$ & $\begin{array}{l}5.111 \\
\pm 1.199\end{array}$ & $\begin{array}{l}3.448 \\
\pm 0.362\end{array}$ & $4.013^{\mathrm{b}}$ \\
\hline 6 & $\begin{array}{l}4.956 \\
\pm 0.352\end{array}$ & $\begin{array}{l}1.672 \\
\pm 0.311\end{array}$ & $\begin{array}{l}6.336 \\
\pm 0.721\end{array}$ & $\begin{array}{l}2.993 \\
\pm 0.564\end{array}$ & $3.989^{b}$ \\
\hline $\begin{array}{l}\text { Combination } \\
\text { factor mean }\end{array}$ & $3.922^{\mathrm{a}}$ & $2.174^{\mathrm{b}}$ & $4.944^{\mathrm{a}}$ & $2.977^{b}$ & \\
\hline
\end{tabular}

Any two means in a row or column having different superscripts (a, b) are significantly different at 5\% level of significance.

Table 3

Effects of FeAA $/ \mathrm{Mn}^{2+} / \mathrm{FeAA}+\mathrm{Mn}^{2+}$ on $\%$ acrosome reaction of bull spermatozoa. (Einfluss von FeAA/Mn ${ }^{2+} / \mathrm{FeAA}+\mathrm{Mn}^{2+}$ auf prozentuale Akrosomenreaktion bei Bullensperma)

\begin{tabular}{|c|c|c|c|c|c|}
\hline \multirow{3}{*}{$\begin{array}{l}\text { Incubationperiod } \\
\text { (hr) }\end{array}$} & \multicolumn{5}{|c|}{$\%$ acrosome reaction } \\
\hline & \multicolumn{2}{|c|}{ FeAA untreated fractions } & \multicolumn{2}{|c|}{ FeAA treated Fractions } & \multirow{2}{*}{$\begin{array}{l}\text { Combination } \\
\text { factor mean }\end{array}$} \\
\hline & Control & $\mathrm{Mn}^{2+}$ & FeAA & $\mathrm{FeAA}+\mathrm{Mn}^{2+}$ & \\
\hline 4 & $\begin{array}{l}72.570 \\
\pm 4.527\end{array}$ & $\begin{array}{l}71.32 \\
\pm 7.300\end{array}$ & $\begin{array}{l}57.76 \\
\pm 3.508\end{array}$ & $\begin{array}{l}70.817 \\
\pm 4.828\end{array}$ & $68.116^{\mathrm{a}}$ \\
\hline 6 & $\begin{array}{l}74.367 \\
\pm 4.572\end{array}$ & $\begin{array}{l}86.141 \\
\pm 5.117\end{array}$ & $\begin{array}{l}72.662 \\
\pm 4.469\end{array}$ & $\begin{array}{l}77.951 \\
\pm 1.016\end{array}$ & $77.780^{\mathrm{b}}$ \\
\hline $\begin{array}{l}\text { Combination } \\
\text { factor mean }\end{array}$ & $73.468^{\mathrm{a}}$ & $78.730^{\mathrm{b}}$ & $65.211^{\mathrm{a}}$ & $74.384^{\mathrm{a}}$ & \\
\hline
\end{tabular}

Any two means in a row or column having different superscripts (a, b) are significantly different at 5\% level of significance.

\section{Discussion}

In our study, \% sperm hyperactivity decreases from $3 \mathrm{hr}$ to $6 \mathrm{hr}$ of incubation. It indicates that during capacitation, motility of spermatozoa decreases gradually and significantly $(\mathrm{P} \leq 0.05)$. Similar observations were made by DHANJU et al., 2006, who reported a 15 to $21 \%$ and 55 to $62 \%$ decline in the percentage motility during incubation of spermatozoa in TALP medium and $0.85 \%$ saline, respectively. Corresponding to the treatments, by inducing oxidative stress, FeAA decreases the \% hyperactivity. It may be explained on the basis of oxidative stress caused by FeAA which deteriorates the membrane 
permeability and integrity, thereby, decreasing the \% hyperactivity or motility (KODAMA et al., 1996). The present study assumes that supplementation of $\mathrm{Mn}^{2+}$ to FeAA treated/untreated samples increases the \% hyperactivity by activating a single transduction cascade.

Following model of signal transduction for the role of $\mathrm{Mn}^{2+}$ in enhancing \% hyperactivity is suggested based on our study and relevant literature (LAPOINTE et al., 1996; GARBERS and KOPF, 1980; ROJAS et al., 1992; TASH and MEANS, 1983). Messenger systems such as adenylate cyclase, guanylate cyclase and calmodulin are highly affected by intracellular salts, such as $\mathrm{Mn}^{2+}, \mathrm{Mg}^{2+}$ and $\mathrm{Ca}^{2+}$. Out of these, $\mathrm{Mn}^{2+}$ is a well known potent stimulator of adenylate cyclase activity, which in turn enhances the level of cAMP (LAPOINTE et al., 1996). Increase in the level of cAMP with the $\mathrm{Mn}^{2+}$ supplementation phosphorylates many proteins that are involved in the movements or flagellar beating of spermatozoa. Increase in the level of cAMP also stimulates the $\mathrm{Ca}^{2+}$ uptake by the cell, thus, increasing the level of intracellular calcium $\left(\mathrm{Ca}_{i}{ }^{2+}\right)$ (GURAYA, 1999). At a higher level, $\mathrm{Ca}_{i}{ }^{2+}$ increase the membrane integrity and viability. These properties of the sperm are required for its optimal functioning under normal and oxidative stress conditions. Elevation of $\mathrm{Ca}_{i}{ }^{2+}$ in flagellum of spermatozoa drives hyperactivation and this action of calcium could be at the level of sperm flagella as revealed by experiments with demembranated rat (LINDEMANN and GOTZ, 1988) and bull (LINDEMANN et al., 1991) spermatozoa.

The previous literature suggest that the intake of $\mathrm{Ca}^{2+}$ is slow during capacitation; but rapid at the time of acrosome reaction. Adequate level of $\mathrm{Ca}^{2+}$ is required in sperm, once the capacitation gets completed (GURAYA,1999). LARSEN (1994) found that high concentration of $\mathrm{Ca}_{i}{ }^{2+}$ is related to the cell death. Based on the present and above studies, it is suggested that supplementation of $\mathrm{Mn}^{2+}$ to the bull spermatozoa permits the rise in $\mathrm{Ca}_{i}{ }^{2+}$ level without decreasing their viability. Further, $\mathrm{Mn}^{2+}$ has beneficial effects on sperm survival and \% hyperactivity during capacitation and acrosome reaction.

The present study also shows that $\mathrm{Mn}^{2+}$ possess the antioxidative property as they decrease the MDA production significantly in both FeAA treated as well untreated samples. $60 \mu \mathrm{M} \mathrm{Mn}^{2+}$ supplementation increases the rate of acrosome reaction under normal and oxidative stress conditions. Thus, on correlating the results of LPO and acrosome reaction, it is suggested that supplementation of $\mathrm{Mn}^{2+}$ to the bull sperm enhances the \% acrosome reaction by decreasing the oxidative stress. As manganese inhibits LPO both in vitro (TAM and McCAY, 1970) and in vivo (SHUKLA and CHANDRA, 1981), it is suggested that its antioxidative property stabilizes the plasma membrane, thereby, maintaining membrane integrity and viability. Therefore, $\mathrm{Mn}^{2+}$ enhance the rate of acrosome reaction in the present study. Similar observations on acrosome reaction have been made, when bull sperms are incubated with $0.1 \mathrm{mM} \mathrm{MnCl}_{2}$ (LAPOINTE et al., 1996). Another possible explanation for the increase in sperm capacitation and acrosome reaction with $\mathrm{Mn}^{2+}$ supplementation is related to the increase in intracellular calcium $\left(\mathrm{Ca}_{i}{ }^{2+}\right)$ content. 
The following model for the role of $\mathrm{Mn}^{2+}$ in sperm capacitation and acrosome reaction is suggested based on our study and relevant literature (GARBERS and KOPF, 1980; TASH and MEANS, 1983;SIDHU et al., 1984; SIDHU and GURAYA, 1989). According to this model, calmodulin or calmodulin-like proteins loosely bind to the plasma membrane and/or $\mathrm{Ca}^{2+}$ or $\mathrm{Mg}^{2+}$-ATPase. These bindings enhance the extrusion of intracellular calcium $\left(\mathrm{Ca}_{i}{ }^{2+}\right)$ and interfere with the capacitation and acrosome reaction processes. However, $\mathrm{Mn}^{2+}$ supplementation stimulates the calmodulin removal from its receptors, thereby, enhancing the $\mathrm{Ca}_{i}{ }^{2+}$ level. As more and more $\mathrm{Ca}_{i}{ }^{2+}$ depositing leads to vesiculation of the acrosome, it causes the fusion of outer acrosomal membrane with the plasma membrane, thus, resulting in acrosome reaction. Extracellular addition of $\mathrm{Mn}^{2+}$ ions also enhance the level of cAMP by stimulating $\mathrm{Ca}^{2+}$ or $\mathrm{Mg}^{2+}$-ATPase which lead to the activation of calcium channel openings, thereby, depositing more $\mathrm{Ca}_{i}{ }^{2+}$. Thus, $\mathrm{Mn}^{2+}$ promotes the acrosome reaction.

Further studies are required to understand the antioxidant strategies or the mechanisms whereby ROS and endogenous antioxidants produced in sperm cells influence the reproductive processes, and ,thereby, promote the fertility of cattle bull spermatozoa.

It is concluded that $\mathrm{Mn}^{2+}$ protects the crossbred cattle bull sperm against LPO / oxidative stress and facilitates the occurrence of capacitation and acrosome reaction.

\section{BANSAL, A. K.:}

\section{References}

Effects of antioxidants on crossbred cattle bull spermatozoa underoxidative stress. Ph.D Thesis. Panjab Agricultural University, Ludhiana, India, 2006

BANSAL, A. K.; BILASPURI, G. S.:

Effect of ferrous ascorbate on in vitro capacitation of crossbred cattle bull spermatozoa. Anim. Sci. Report.1 (2007), 69-77

BANSAL, A. K.; BILASPURI, G. S.:

Effect of ferrous sulphate and ascorbic acid on motility, viability and lipid peroxidation of crossbred cattle bull spermatozoa. Animal. (In press), 2008

BUEGE, J. A.; STEVEN, A. D.:

In:Colowick S P and Kalpan NO (eds) Method in Enzymology, Biomembranes ; Part-C :Biological oxidants; eds Fleischers and Pecker L), Academic Press, New York, 52, 302-310,1978

CAVALLINI, L.; VALENTE, M.; BINDOLI, A.:

On the mechanism of inhibition of lipid peroxidation by manganese. Inorganica. Chimica. Acta., 91 (1984), $117-120$

COASSIN, M.; URSINI, F.; BINDOLI, A.:

Antioxidant effect of manganese. Arch. Biochem. Biophys., 299 (1992), 330-333

de LAMIRANDE, E.;GAGNON, C.:

Human sperm hyperactivation in whole semen and its association with low superoxide capacity in seminal plasma. Fert. Steril., 59 (1993), 1291-1295

de LAMIRANDE, E.; GAGNON, C.:

Impact of reactive oxygen spcies on spermatozoa: a balancing act between beneficial and detrimental effecs Hum. Reprod., 10 (1995), 15-21

DHANJU, C. K.; KAUR, R.; CHEEMA, R. S.:

Protein-leakage during heparin -induced in vitro capacitation of bull sperm. Arch. Tierz., Dummerstorf, 49 (2006), 426-433 
GARBERS, D. L.; KOPF, G. S.:

The regulation of spermatozoa by calcium and cyclic nucleotides. In:Greengard P and Roinson G A (ed). Advances in Cyclic Nucleotides Research , Raven Press, New York, 251-305,1980

GURAYA, S. S.: Cellular and molecular biology of capacitation and acrosome reaction in spermatozoa. Int. Rev. Cytol., 199 (1999), 1-66

KODAMA, H.; KURIBAYASHI, Y.; GAGNON, C.: Effect of sperm lipid peroxidation on fertilization. J. Androl., 17 (2) (1996), 151-157

KUMAR, H.; MAHMOOD, S.: The use of fast acting antioxidants for the reduction of cow placental retention and subsequent endometritis. Indian. J. Anim. Sci., 71 (7) (2001), 650-653

LAPOINTE, S.; AHMAD, I.; BUHR, M. M.; SIRARD, M. A.:

Modulation of post-thaw motility, survival, calcium uptake and fertility of bovine sperm by magnesium and manganese. J. Dairy. Sci., 79 (12)(1996), 2163- 2169

LARSEN, C. J.:

The $\mathrm{BCL}_{2}$ gene is a prototype of a gene family that controls programmed cell death (apoptosis). Anales. Genet., 37 (1994), 121

LINDEMANN, C. B.; GOTZ, J. S.:

Calcium regulation of flagellar curvature and swimming pattern in triton X-100 extracted rat sperm. Cel.l Motil. Cytoskeleton., 10 (1988), 420

LINDEMANN, C. B.; KANOUS, K. S.; GARDNER, T. K.: The interrelationship of calcium and cAMP mediated effects on reactivated mammalian sperm models in comparative spermatology : 20 years after edited by Bacetti B.Ed. Raven Press, New York, 491, 1991

MILLER, J. K.; SLEBODZINSKA, E. B.: Oxidative stress, antioxidants and animal function. J. Dairy. Sci., 76 (1993), 2812-2823

O’FLAHERTY, C.; BECONI, M.; BEORLEGUI, N.: Effect of natural antioxidants, superoxide dismutase and hydrogen peroxide on capacitation of frozen thawed bull spermatozoa. J. Andrology., 29 (5) (1997), 269-75

O’FLAHERTY, C.; de LAMIRANDE, E.; GAGNON, C.:

Reactive oxygen species and protein kinase modulate the level of phosphor-MEK like protein during human sperm capacitation. Biol. Reprod., 73 (2005), 94-105

PARRISH, J. J.; PARRISH, S.; GRAHAM, J. K.: In vitro capacitation of bovine spermatozoa: role of intracellular calcium. Theriogenol., 51 (1999), 461-472

ROJAS, F. J.; BRUZZONE, M. E.; ROJAS, M. I.: Regulation of cyclic adenosine monophosphate synthesis in human ejaculated spermatozoa. II. The role of calcium and bicarbonate ions on the activation of adenylyl cyclase. Hum. Reprod., 7 (1992), 1131

SHUKLA, G. S.; CHANDRA, V. C.: Manganese toxicity : Lipid peroxidation in rat brain. Acta.Pharmacol.Toxicol., 48 (1981), 95

SIDHU, K. S.; GURAYA, S. S.: Cellular and molecular biology of capacitation and acrosome reaction in mammalian spermatozoa. Int. Rev. Cytol., 98 (1989), 237-280

SIDHU, K. S.; SUNDHEY, R.; GURAYA, S. S.:

Stimulation of capacitation and the acrosome reaction in ejaculated buffalo (Bubalus bubalis) sperm and the effect of a sperm motility factor. Int. J. Androl., 7 (1984), 324-333

SIKKA, S. C.:

Oxidative stress and role of antioxidants in normal and abnormal sperm function. Frontiers. Biosci., 1 (e) (1996), 78-86

SINGH, A.:

Importance of manganese in human body . Proc. $11^{\text {th }}$ Punjab Sci. Cong., Thapar Univ., Patiala, India, 69 (2008)

TAM, B. K.; McCAY, P. B.:

Reduced triphosphoryridine nucleotide oxidase catalyzed alterations of membrane phospholipids 3 transietn formation of phospholipids peroxides. J. Biol. Chem., 245 (1970), 2295-2300

TASH, J. S.; MEANS, A. R.:

Cyclic adenosine 3'-5' monophosphate, calcium and protein phosphorylation in flagellar motility. Biol. Reprod., 28 (1983), 75 
VERMA, A.; KANWAR, K.C.:

Effect of vitamin E on human sperm motility and lipid peroxidation in vitro . Asian. J. Androl., 1 (1999), 151-154

Received: 2007-03-30

Accepted: 2008-02-27

Corresponding author

Dr. G. S. Bilaspuri

Department of Animal Breeding \& Genetics

Guru Angad Dev Veterinary \& Animal Sciences University,

Ludhiana, India

phone: 91-0161-2414003 (O)

email: bansal2amrit@yahoo.co.in 